\title{
Water Users Associations and irrigation water use efficiency in costal oases areas in Gabès, Southeastern Tunisia
}

\author{
Naceur Mahdhi ${ }^{\star}$, Boubaker DhehibI ${ }^{\star \star}$, Annelies Brokman ${ }^{\star \star \star}$, \\ FARAH ChOUIKHI*
}

DOI: $10.30682 / \mathrm{nm} 2101 \mathrm{~b}$

JEL codes: Q12, Q25, R15

\begin{abstract}
The objective of this study was to measure the efficiency level of Water Users Associations (WUAs) in the coastal oases of Gabès (Southeastern Tunisia) and to assess its main determinants. First, an input-oriented data envelopment analysis (DEA) was used to measure the relative efficiency scores of WUAs and to evaluate the management and maintenance costs sub-vectors efficiencies separately through a mathematical modification in the initial DEA specification. In a second stage, critical determinants of sub-vector efficiency are determined by applying a Tobit model. A key finding of the study is that WUAs are clearly inefficient. Results show that on average, $36 \%$ of the used inputs (management and maintenance costs) could be saved if the WUAs operated on the frontier. The inefficiency found can be mainly attributed to the number of water pumping stations managed, the ratio of water losses and the WUAs'age. The results also show a discrepancy between the technical efficiency values calculated under the CRS and VRS assumptions, resulting in a $20 \%$ scale inefficiency. The study also revealed that the sub-vector inefficiency of WUAs is linked more to engineering inefficiencies than to inefficiencies in their management.
\end{abstract}

Keywords: WUA, Coastal oases, DEA method, Technical efficiency, Sub-vector efficiency, Tunisia.

\section{Introduction}

Water scarcity has become a main challenge for the world, with increasing demand resulting from the growing population, accelerating economic development, and rapid urbanization (Yilmaz et al., 2009; Zhou et al., 2017). Globally, irrigation water is becoming an increasingly scarce resource for agriculture in Tunisia and in many regions of the world (Hamza, 2008;
Abdelhafidh and Bachta, 2016; Ben Nasr and Bachta, 2018; Mahdhi et al., 2011; Mahdhi and Sghaier, 2013; Zema et al., 2018; Mahdhi et al., 2019). Tunisia is placed in the category of the least water resources-endowed countries in the Mediterranean basin (ITES-Institut Tunisien des études stratégiques, 2011; 2014; Elloumi, 2016). Overall, water reserves in the country are estimated at 4.7 billion $\mathrm{m}^{3} /$ year, of which 2.7 bil-

\footnotetext{
* Agricultural economics and rural society laboratory, Institute of Arid Regions of Medenine, Tunisia.

** International Center for Agricultural Research in the Dry Areas (ICARDA), Beirut, Lebanon.

*** Centre for Ecological Research and Forestry Applications (CREAF), Barcelona, Spain.

Corresponding author: naceur.mahdhi@ira.rnrt.tn
} 
lion $\mathrm{m}^{3}$ comes from annual rivers in the north, 0.7 billion $\mathrm{m}^{3}$ from groundwater in the Centre, plains and coastal areas, and about 1.3 billion $\mathrm{m}^{3}$ from the deep groundwater mainly in the south (MA-Ministry of Agriculture and Water Resources, 2016). Water resources are unevenly distributed across the country, with around $60 \%$ in the north, $18 \%$ in the center and $22 \%$ in the south (MA, 2016). Water resources with a salinity lower than $1.5 \mathrm{~g} /$ liter are distributed as follows: $72 \%$ of surface water resources, $8 \%$ of shallow groundwater and $20 \%$ of deep groundwater (Louati, 2008; MA, 2013).

The agricultural sector, which accounts for approximately $8 \%$ of the GDP, is the largest consumer of water, and irrigation accounts for some $85 \%$ of water withdrawals from 212 shallow aquifers (containing $719 \times 10^{6} \mathrm{~m}^{3}$ ) and 267 deep aquifers (MA, 2016; INS-Institut National de Statistique, 2016). In 2016, about 444 thousand hectares ( $9 \%$ of useful agricultural land) are irrigated in Tunisia (MA, 2016). Irrigated agriculture represents $37 \%$ of the output value derived from the agricultural sector, $20 \%$ of exports, and $27 \%$ of agricultural employment (MA, 2016). Irrigated areas provide $95 \%$ of horticultural crops and $30 \%$ of dairy production (MA, 2013). Moreover, the efficiency of the irrigation networks is relatively weak, estimated at approximately 50\% (Bachta and Ghersi, 2004). Therefore, during recent decades, concerns regarding the efficient use of water resources in the country have been raised (Belloumi and Matoussi, 2007; Mahdhi and Sghaier, 2013; Frija et al., 2014; Abdelhafidh and Bachta, 2016). These concerns have been addressed particularly through significant investments, reaching $8,3 \%$ of total investments in the government's Development Plan XII (2011-2015) and through the transfer of the management of collective irrigation schemes to the users through the creation of water user associations (WUAs) (MA, 2010; Makkaoui and Dubois, 2010; Mahdhi and Sghaier, 2017). The WUAs have been created through government investments, but they are responsible to ensure the collection of water fees as well as service-related fees (e.g., infrastructure maintenance) (Bachta and Zaïbet, 2007; Romagny and
Riaux 2007; Makkaoui and Dubois, 2010; Ben Nasr and Bachta, 2018).

The number of WUAs has increased from about 100 in 1993 to 1160 in 2009, managing around 220000 hectares of irrigated lands (MA, 2016; Elloumi, 2016). Annually, each WUA is responsible for the elaboration of its own budget, as well as for choosing the water price and deciding whether payments are to be made on the basis of water volumes to be produced or distributed. Furthermore, WUAs establish the amount of projected investments and the operation and maintenance charges. Financially, WUAs perform the following tasks: operation and maintenance of canals, repairing of various infrastructures, the management of the association and investments (Frija et al., 2009; Ben Nasr and Bachta, 2018).

The transfer of the management of collective irrigation schemes to WUAs has tried to stimulate water productivity, provide the farmers' participation, and thereby simultaneously achieving economic and ecological benefits (Romagny and Riaux, 2007; Zhang et al., 2013; Özmen and Kamanb, 2015; Zema et al., 2015). However, the objectives of achieving a positive impact on resource productivity, equity, full cost recovery and environmental sustainability are not always met (Romagny and Riaux, 2007; Makkaoui and Dubois, 2010; Frija et al., 2014; Ben Mustapha et al., 2016; Abdelhafidh and Bachta, 2016; Ben Mustapha and Fyasse, 2017). In Tunisia, only $25 \%$ of WUAs succeeded in covering their entire operation and maintenance costs, while $25 \%$ of them covered even less than $50 \%$ and were still subsidized by the government (Al Atiri, 2007; Marlet and Mnajja, 2017). However, problems differ from one WUA to another, with only some associations eligible to be considered efficient (Al Atiri, 2007; Ben Mustapha et al., 2015; Marlet and Mnajja, 2017; Ben Mustapha and Fyasse, 2017).

In oases areas, WUAs are still facing a wide range of financial, technical, and organizational constraints (Romdahne and Abdelathim, 2008; Abdedayem, 2009; Ghazouani et al., 2012; Ouneis, 2018). Among the main problems, there are: insufficient maintenance and repair services, challenges in the collection of water fees, 
the need for rehabilitation of facilities, inadequacy of new investments and failure to encourage producers to participate in the management of irrigation systems (Romdhane et al., 2006; Romdahne and Abdelathim, 2008; Boukchina and Abdedayem, 2008; Abdedayem, 2009; Carpentier, 2017; Ouneis, 2018). The efficiency analysis revealed that some WUAs are suffering from small-scale management (Belloumi and Matoussi, 2007; Ghazouani et al., 2012; Emlyaeih, 2016). A major reorganization is deemed necessary to further improve the management of WUAs for the efficient water use and farmer welfare. This paper tries to address the relative performance of WUAs in terms of management and engineering efficiencies in oases areas of Gabès (Southeastern Tunisia), and to identify critical technical and organizational determinants of efficiencies. Many methodologies can be used for this purpose, ranging from a simple visual comparison of performance data to relatively sophisticated mathematical methods (Diaz Rodriguez et al., 2004; Zema et al., 2015; Zema et al., 2018).

This study proposes the use of the data envelopment analysis (DEA) approach. This method is based on linear programming techniques that define the production function and determine the efficiency frontier of a set of decision-making units (DMUs). With a series of inputs and outputs for each irrigation district, DEA allows to assess the relative efficiency of a given district and to obtain the optimal configuration by numerically assigning to each irrigation district its objective (Diaz Rodriguez et al., 2004;). In fact, many studies have used the DEA methodology to analyze the organizational efficiency. The applications range from banks, health and educational institutions and forest organizations to airlines and railway companies (Diaz Rodriguez et al., 2004; Mahdhi et al., 2014). To our knowledge, the application undertaken in this paper to assess the efficiency of organizations specializing in water management is still limited (Umetsu et al., 2005; Ghazouani et al., 2012; Mahdhi et al., 2014). In the irrigation and drainage sectors, DEA has often been applied to estimate the production efficiency of large irrigated systems and districts at regional level (Malano et al., 2004;
Zema et al., 2015; Zema et al., 2018). In our study, we assume that DEA is not only suitable to apply in the case of water management associations, but moreover, the methodology used allows for the calculation not only of overall but also of sub-vector efficiencies (for alternatives see Oude Lansink et al., 2002; Speelman et al., 2007). Management and engineering efficiencies were assessed using the concept of sub-vector efficiencies. As a matter of fact, through management efficiency, we try to express how well a given WUA allocates expenditure to manage the organization and the functioning of the WUA, compared to the rest of the WUAs in the sample. In the same sense, engineering efficiency expresses the performance of a given WUA in allocating expenditure for maintenance tasks, concerning the rest of the WUAs in the sample studied. Maintenance expenditure includes expenses related mainly to the maintenance and repairing of the irrigation network and the pumping stations. Energy costs (for WUAs that pump water from boreholes) and the labor cost of performing the above-mentioned tasks are also included in the maintenance expenditure vector. In a second step, a Tobit model was estimated to provide ideas about local inefficiencies and to determine potential factors affecting the functioning of WUAs. To achieve these objectives, the paper is divided into four separate sections. After the introduction, in section 2, we describe the DEA technique, the Tobit model used in this study as well as the study area and data collection. Results and discussions are presented in the last section, after which the most important conclusions are drawn.

\section{Methods and data}

\subsection{DEA models}

Based on the work of Farrell (1957), DEA was developed by Charnes et al. (1978) as an empirical frontier analysis technique. This method is based on linear programming techniques that define the production function and determine the efficiency frontier of a set of decision-making units (DMUs). According to Farrell (1957), the technical efficiency reflects the ability of a DMU 
to produce maximum output given a set of inputs or, alternatively, to achieve maximum feasible reductions in input quantities when output values are given. With a series of inputs and outputs for each irrigation district, DEA allows to assess the relative efficiency of a given district and to obtain the optimal configuration by numerically assigning to each irrigation district its objective (Diaz Rodriguez et al., 2004). The main advantages of the DEA approach are that it does not require any specific function of production process subject to multiple inputs and outputs, and the efficiency of a DMU is measured by comparing it with an ideal unit that achieves better performance measurement rather than being compared based on average values. Although DEA have some powerful advantages mentioned above, the main limitation in the method is that it does not account for random data error, which can be significant in agriculture (Diaz Rodriguez et al., 2004). Additionally, even if the DEA approach has been widely and successfully used in different areas, its application to assess the efficiency of organizations specialized in water irrigation management is limited in the available literature (Diaz Rodriguez et al., 2004; Frija et al., 2008; Yilmaz et al., 2009), particularly in costal oases areas. In this study, performances of WUAs in management, operation, and maintenances services (MOM) of costal oases irrigations schemes were evaluated.

The application of the DEA method can be oriented in inputs or outputs, with different objectives set from these two models. The input-oriented model aims to continue producing the same outputs while minimizing the inputs, whereas the output-oriented model aims to maximize outputs using the minimum number of inputs.

Technical efficiency can be decomposed into two components: pure technical efficiency (TEvrs) and scale efficiency (SE). Scale efficiency relates to the most efficient scale of operation, in the sense of maximizing average productivity. If there is a difference between scores of technical efficiency under Constant Returns to Scale (CRS) and Variable Returns to Scale (VRS) for a certain farm, the difference indicates that a farmscale is inefficient. Scale efficiency measures can be calculated by dividing the total technical efficiency by pure technical efficiency.
One of the analysis options in DEA is a choice between CRS and VRS. CRS assumes that there is no significant relationship between the efficiency and the scale of operation, thus assuming that large WUAs are just as efficient as small ones in converting inputs to outputs. Furthermore, we assume that changes in the organization's inputs can lead to disproportionate changes in its outputs. Therefore, the option of VRS will be chosen in this study. A second option is a choice between input-oriented and output-oriented DEA models. If the focus is to use different resources more efficiently (instead of increasing production), then the suitable model to use is an input-oriented one (Diaz Rodriguez et al., 2004). In our case, it is necessary, as a national objective of the decentralization process, that WUA reaches a cover rate of their expenditures ensuring their sustainability. In addition, the volume of water that a given WUA purchases from the regional water management administration is planned and fixed at the beginning of the year. This value being fixed is necessary for the determination of water rates in the WUA. Therefore, during the agricultural year, the WUA will focus mainly on the minimization of their expenditure. For these reasons, it is estimated that an input-oriented model will be more suitable for our problem. In summary, we chose to estimate the Variable Return to Scale (VRS) efficiencies through BCC (Banker et al., 1984) and the input-oriented model.

Following the BCC model, if we consider $\mathrm{K}$ $\operatorname{DMU}(\mathrm{k}=1 \ldots \mathrm{K})$ each of them uses $\mathrm{N}$ inputs variables xnk $(n=1, \ldots, N)$, for producing M outputs ymk $(\mathrm{m}=1, \ldots, \mathrm{M})$. Each DMU0 becomes the reference unit and then we have to resolve the following linear program $\mathrm{k}$ times (once for each DMU):

$$
\begin{aligned}
& \operatorname{Min}_{\theta, \lambda} \lambda^{\theta} \sum_{\mathrm{k}=1}^{\mathrm{K}} \lambda_{\mathrm{k}} \mathrm{y}_{\mathrm{m}, \mathrm{k}} \geq \mathrm{y}_{\mathrm{m}, 0} \\
& \sum_{\mathrm{k}=1}^{\mathrm{K}} \lambda_{\mathrm{k}} \mathrm{x}_{\mathrm{n}, \mathrm{k}} \leq \theta \cdot \mathrm{x}_{\mathrm{n}, 0} \\
& \sum_{\mathrm{k}=1}^{\mathrm{K}} \lambda_{\mathrm{k}}=1 \\
& \lambda_{\mathrm{k}} \geq 0
\end{aligned}
$$

(equation 1) 
where $\theta$ is a variable representing the efficiency of the reference $\mathrm{DMU}_{0}$, hence the percentage of reduction that each input must be subjected to reach the production frontier. $\lambda_{\mathrm{k}}$ is a vector of $\mathrm{k}$ elements representing the influence of each DMU in determining the efficiency of the DMU0. The term $\sum_{\mathrm{k}=1}^{\mathrm{K}} \lambda_{\mathrm{k}} \mathrm{y}_{\mathrm{m}, \mathrm{k}}$

indicates the weighted sum of outputs of all DMU, which must be superior or equal to the output of $\mathrm{DMU}_{0}$ (constraint 2). In constraint 3, $\theta$ is the measure of technical efficiency and represents, at the same time, the minimized objective. The estimate will satisfy restriction $\theta \leq 1$ with a value $\theta=1$, indicating a technically efficient farm. Equation 4 consists of the convexity constraint, which specifies a variable return to scale option. The DMUs whose $\lambda$ values are positive will be the reference set for $\mathrm{DMU}_{0}$ under study. As a matter of fact, it is the linear combination of those units which will formulate the situation objective needed to become efficient.

It should also be noted that equation 1 has a variable return to scale (VRS) specification, which includes a convexity constraint $\sum_{\mathrm{k}=1}^{\mathrm{K}} \lambda_{\mathrm{k}}=1$.

Without that constraint, equation (1) would have constant returns to scale specification (CRS). Using that specification, it is assumed that farms are operating at their optimal scale (Oude Lansink and Silva, 2004). In the case of agriculture, increased amounts of inputs do not proportionally increase the amount of outputs. For instance, when the amount of water for crops is increased, a linearly proportional increase in crop volume is not necessarily obtained; one reason why the variable return to scale option might be more suitable for our problem (Diaz Rodriguez et al., 2004).

To calculate the efficiency of the use of an individual input or subset of inputs, the "sub-vector efficiency" concept can be introduced. The sub-vector efficiency measure looks at the possible reduction in the selected subset of inputs holding all other inputs and outputs constant (Oude Lansink et al., 2002; Oude Lansink and Silva, 2004). Using the notion of sub-vector efficiency proposed by Färe et al. (1994) in Oude Lansink et al., 2002, technical sub-vector efficiency for variable input $t$ is calculated for each firm $\mathrm{i}$ by solving the following linear programming (LP) problem (equation 2):

$$
\operatorname{Min}_{\theta^{t}, \lambda} \theta^{\mathrm{t}}
$$

s.t.

$$
\begin{aligned}
& \sum_{k=1}^{K} \lambda_{\mathrm{k}} y_{m, k} \geq \mathrm{y}_{\mathrm{m}, 0} \\
& \sum_{k=1}^{K} \lambda_{\mathrm{k}} x_{\mathrm{n}-\mathrm{t}, \mathrm{k}} \leq x_{n, 0} \\
& \sum_{k=1}^{K} \lambda_{\mathrm{k}} x_{t, k} \leq \theta^{t} x_{t, 0} \\
& \sum_{k=1}^{K} \lambda_{k}=1 \\
& \lambda_{\mathrm{k}} \geq 0
\end{aligned}
$$

where $\theta^{\mathrm{t}}$ is the input $t$ sub-vector technical efficiency score for the $\mathrm{DMU}_{0}$ under study. The measure $\theta^{t}$ represents the maximum reduction of variable input $t$ holding outputs and all remaining inputs $(n-t)$ constant. All other variables are defined as in program (1). Therefore, the input $t$ sub-vector technical efficiency model involves finding a frontier that minimizes the quantity of input $t$ (Oude Lansink et al., 2002).

\subsection{Tobit model and variables identification}

After calculating the efficiency measures, the next step is to identify the determinants of inefficiency; something is commonly done by estimating a second-stage relationship between the efficiency measures and suspected correlates of efficiency (Binam et al., 2003). Since the efficiency parameters vary between $0-1$, they have censored variables. Consequently, a Tobit model needs to be used (equation 3):

$$
\begin{gathered}
\theta^{t^{*}}=\sum_{i=1}^{N} \beta_{i} Z_{i}+\varepsilon_{i} \\
\theta^{t}=\left\{\begin{array}{l}
\theta^{t^{*}} \text { if } 0 \prec \theta^{t^{*}} \prec 1 \\
=0 \text { if } \theta^{t^{*}} \prec 0 \\
=1 \text { if } \theta^{t^{*}} \succ 1
\end{array}\right.
\end{gathered}
$$

where $\theta^{t}$ are the DEA overall, scale, management, and engineering efficiencies used as dependent variables and $\mathrm{Z}$ is an $\left(N^{*} 1\right)$ vector of 
independent variables related to attributes and characteristics of WUAs in the sample. The estimation of the Tobit model is based on maximum likelihood procedures. For Tobit estimates to be consistent, it is necessary that residuals $\left(\varepsilon_{i}\right)$ are normally distributed (Holden, 2004). The empirical estimates of the second stage were conducted using the STATA ver. 10.

\subsection{Research area and data collection}

The study area envisaged is part of the coastal oases area of Gabès (Figure 1). In terms of climate, this area is located in the Mediterranean bioclimatic zone (rainy winters and dry summers). Its climate, arid to Saharan, is characterized by irregular and sporadic precipitations (less than $200 \mathrm{~mm}$ ) (the coefficient of variation exceeds 50\%) (Abdedayem, 2009). Groundwater resources are the main source of water that can be exploited in the coastal oases area of Gabès (CRDA Gabès, 2017). These resources are formed by two types of aquifers: the continental, intercontinental and Jeffara slicks. Both aquifers are under intense pressure that continues to increase due to rapid population growth and a remarkable extension of the irrigable po- tential to 19236 ha and the number of water points equipped with 150 boreholes (CRDA de Gabès, 2017). This overexploitation has been exacerbated in recent years by the spread of illegal wells (Boukchina and Abdedayem, 2008; Abdedayem, 2009). Two subsystems can be distinguished: the subsystem of private irrigated farms is based on surface wells; the subsystem of public irrigation schemes is based on collective tube-wells. The collective irrigated area expands over 13623 ha, representing $70.82 \%$ of irrigated area in the governorate of Gabès (CRDA Gabès, 2017). Farmers commonly use collective irrigation systems, managed by about 100 WUAs. Agricultural production is based on crop production and the irrigation system is characterized by surface irrigation methods. According to the CRDA Gabès (2017), the main crops produced in the study area are fruits $(58 \%)$, vegetables $(20 \%)$, forage crops $(21 \%)$ and others (1\%). The total agricultural production of this region contributes to nearly $43 \%$ of the total regional agricultural production and provides $37 \%$ of the agricultural labour force.

Data used in this study refer to 2019 and cover 61 WUAs operating in 8 irrigated districts of Gabès Sud, Mareth, Gannouch, Matmata Eljadida, Hemma, Metouia, Gabès Ouest and Gabès

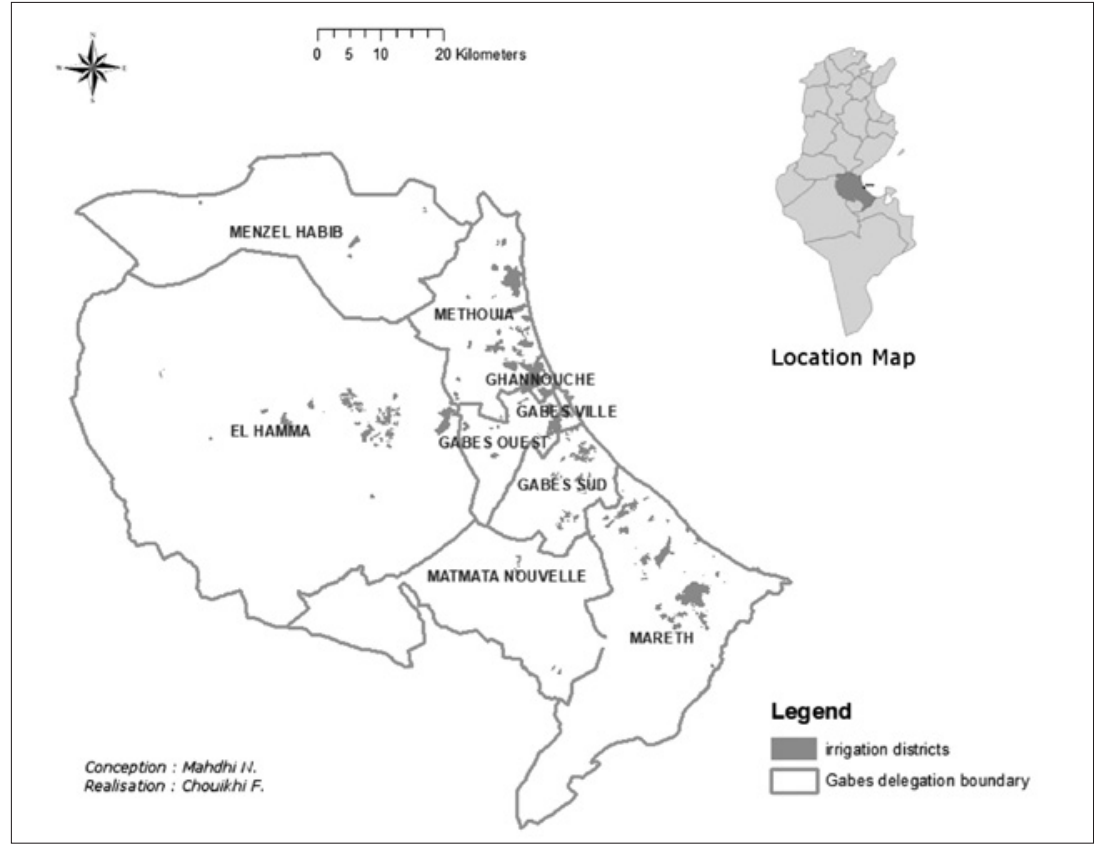

Figure 1 - Location of the study area, irrigation districts. 
Ville (Figure 1). These districts cover $43 \%$ of the total irrigation areas in the governorate of Gabès. The required data were obtained from the annual reports of the WUAs and the annual monitoring and evaluation reports prepared by regional CRDA. Available data include the volumes of consumed water and the total irrigated areas of each irrigation system, management, maintenance, and repairing cost.

\subsection{Technical, management, and engineering efficiencies}

For the purpose of efficiency analysis, naturally, it is relatively easier to define the inputs and outputs when the irrigation system is assimilated to the DMU. In contrast, the definition of inputs and outputs becomes more complicated when irrigation organizations (WUAs) are considered as the DMUs (Sayin and Yilmaz, 2015). This is particularly associated with the amount of water being taken into account. The main function of irrigation organizations is to make water from their supply available for use by farmers. Therefore, the amount of water provided and other associated variables (i.e., water purchase cost if the water is purchased (Mahdhi et al., 2014)) can be used as inputs, and the amount of water used by farmers and other associated variables can be used as outputs (Malano et al., 2004; Mahdhi et al., 2014; Sayin and Yilmaz, 2015). The size of the irrigated area and the quantity of water distributed per irrigated area are major indicators employed in comparing irrigation organizations in the literature (Malano et al., 2004; Frija et al., 2009). These two outputs are the only constant and stable WUA outputs in the short run. The financial revenue of the WUA, which could be a relevant output to consider, can always change from one year to another according to the objective of the association. Other data related to some productive performance indicators (total gross annual agricultural production in the area managed by the WUA; total annual value of agricultural production; output per unit service area, etc.) was not available. Therefore, the analyses are carried out by considering the output as the annual irrigated area (ha) and the total annual irrigation water delivery per unit irrigated area $\left(\mathrm{m}^{3} \mathrm{ha}^{-1}\right)$. Concerning the selection of inputs, according to the database, the WUA expenditures can mainly be divided into management expenditures, maintenance costs, water purchasing costs, labor costs, investments, reimbursements of debts and other expenditures. Given that in our empirical application we try to focus on the relationship between inputs-outputs of the WUAs within a general framework of minimization of irrigation water prices, we choose to aggregate the main financial inputs of the water users' associations into management expenditure, maintenance expenditure, and purchasing water expenditure. These expenditure vectors were always used as inputs for DEA models to analyze the efficiency of organizations (Frija et al., 2009; Sayin and Yilmaz, 2015). Therefore, the analyses are carried out by considering the input as the management costs and maintenance costs, which consist of expenditures made by the irrigation union to maintain its function and internal organizational structure.

Management costs that were considered as inputs include the wages and daily allowances of personnel employed in the irrigation union, vehicle rental charges, vehicle fuel costs, book-keeping and office expenses. The maintenance costs include the wages of personnel employed for maintenance and repairing work, the cost of pumping energy-related, rental charges, fuel expenses and repair costs for vehicles used in maintenance work, and facility maintenance and repair costs. It was expected that the decreasing in management, maintenance, and repair costs would increase the TE.

In the sub-vector management efficiency, only the efficiency of the individual management expenditure input is considered, while holding the rest of inputs and outputs constant. Generally, management expenditures are stable over time (Terraux et al., 2002). The engineering sub-vector efficiency considers the inputs related to the total expenditure on maintenance (labor, energy, and other maintenance expenditures). In the short term, this input gives an idea on the efficiency of the maintenance tasks and on the technical network situation of the WUA. Only the efficiency of this latter individual input will be considered in the calculation of the sub-vector engineering efficiency while keeping the rest of the input vectors constant. 
Table 1 - Basic statistics for the data used in the DEA Model.

\begin{tabular}{|l|c|c|c|c|}
\hline & \multicolumn{2}{|c|}{ Outputs } & \multicolumn{2}{c|}{ Inputs } \\
\hline & $\begin{array}{c}\text { Irrigated area } \\
\left(\text { ha } \mathrm{yr}^{-1}\right)\end{array}$ & $\begin{array}{c}\text { Volume of water } \\
\text { distributed } \\
\mathrm{ha}^{-1}\left(\mathrm{~m}^{3}\right)\end{array}$ & $\begin{array}{c}\text { Management costs } \\
(\text { TDN/year })\end{array}$ & $\begin{array}{c}\text { Maintenance costs } \\
\text { (TDN/year) }\end{array}$ \\
\hline Average & 108 & 7656 & 14,859 & 37,828 \\
\hline Standard deviation & 81.22 & 4836 & 10,714 & 25,807 \\
\hline Minimum & 15 & 1188 & 4,250 & 3,000 \\
\hline Maximum & 450 & 26280 & 61,400 & 110,225 \\
\hline
\end{tabular}

Source: Own elaboration based on data survey (2019).

Descriptive statistics concerning the selected outputs and inputs are displayed in Table 1. In the research area, approximately 7271 farmers are operating in a farming area for about 8310 ha. The average irrigated varied between 15 and 450 ha, with an average of 108 ha. The total volume of water distributed and managed by the existing WUAs is around $51 \times 10^{6} \mathrm{~m}^{3}$ (i.e., around $7656 \mathrm{~m}^{3} /$ ha on average). The management, maintenance and repairing costs depend on the size of WUA, varying from 110,225 TDN to $3,000 \mathrm{TDN}$.
In the Tobit analyses, various WUA-specific factors are analyzed to assess their influence on the sub-vector management efficiency and the engineering sub-vector efficiency. The explanatory variables in the inefficiency effects include technical, organizational, and administrative characteristics, given by the number of pumping stations managed by the WUA, the ratio of irrigated area, the ratio of water losses and the age of the association, the ratio of adherent to the WUA and to the number of members of the administrative council (Table 2).

Table 2 - Definition for variables used in the Tobit regression.

\begin{tabular}{|l|l|c|}
\hline Variable & Definition & Mean value \\
\hline Technical characteristics of the irrigated district & 32.85 \\
\hline N. of years in function & Years of experience operating a WUA & 121.66 \\
\hline N. of water pumping stations & $\begin{array}{l}\text { Number of water pipes. Each pipe is used by a group of } \\
\text { farmers }\end{array}$ & 22.5 \\
\hline Resource size (km) & $\begin{array}{l}\text { The length of irrigation water carrier (pipelines and } \\
\text { surface channel) }\end{array}$ & 22.3 \\
\hline The ratio of water losses & $\begin{array}{l}\text { The initial quantity of water held by the } \\
\text { WUA/distributed quantity of water }\end{array}$ & $\begin{array}{l}\mid \\
\text { Area exploited, managed and } \\
\text { irrigated/exploitable area }\end{array}$ \\
\hline $\begin{array}{l}\text { Irrigation ratio } \\
\text { Administrative and organizational characteristics of the WUA }\end{array}$ & \begin{tabular}{l} 
\\
\hline $\begin{array}{l}\text { The ratio of farmers who are } \\
\text { members of WUAs }\end{array}$
\end{tabular} & $\begin{array}{l}\text { Number of adherents belonging to the WUA's } \\
\text { geographical limits }\end{array}$ \\
\hline $\begin{array}{l}\text { N. of members in the } \\
\text { administration council }\end{array}$ & \multicolumn{1}{|l}{3.6} \\
\hline
\end{tabular}

Source: Own elaboration based on data survey (2019). 


\section{Results}

\subsection{Efficiency analysis results}

The technical efficiency (equation 1) is estimated using the program DEAP (Coelli, 1996).

Management and engineering sub-vectors efficiencies (equation 3) were modelled in the General Algebraic Modelling System software (GAMS) using the methodology proposed by Speelman et al. (2007). Summary statistics of calculated efficiency are presented in Table 3.

For all three efficiencies, the maximum measure found within the sample is unity. The percentage of efficient farms (WUA) represents the share of farms with an efficiency measure of unity. Minimum and maximum values of efficiency scores show considerable variability among farms and districts. The average efficiency provides information about the potential resource savings that could be achieved while maintaining the same output level.

Based on the results of the model efficiency, technical efficiency scores are 51\% and 64\% respectively, under CRS and VRS assumptions (Table 3). These values indicated that (all) inputs (management and maintenance costs) can be reduced by $49 \%$ and $36 \%$, respectively, without any decrease in irrigation services.

As Table 3 indicates, $80 \%$ irrigation schemes are not technically efficient under VRS assumption, and $57.37 \%$ of them have technical efficiency scores below the average technical efficiency score of 0.64. At the same time, the average scale efficiency scores of inefficient schemes reached 0.80 . Further, $85.24 \%$ of the schemes show scale efficiency scores exceeding the average efficiency score. This result suggests that it is due to managerial inefficiency rather

Table 3 - Overall technical, management, and engineering efficiencies under constant and variable returns to scale specification.

\begin{tabular}{|l|c|c|c|c|c|c|}
\hline \multirow{2}{*}{$\begin{array}{c}\text { Efficiency } \\
\text { score (\%) }\end{array}$} & \multicolumn{2}{|c|}{ Overall technical efficiency } & Management efficiency & \multicolumn{2}{c|}{ Engineering efficiency } \\
\cline { 2 - 7 } & CRS & VRS & CRS & VRS & CRS & VRS \\
\cline { 2 - 7 } $0-10$ & 0 & 0 & 2 & 0 & 2 & 0 \\
\hline $10-20$ & 2 & 0 & 2 & 0 & 3 & 2 \\
\hline $20-30$ & 13 & 8 & 13 & 8 & 16 & 10 \\
\hline $30-40$ & 23 & 15 & 21 & 15 & 26 & 20 \\
\hline $40-50$ & 25 & 16 & 25 & 18 & 20 & 13 \\
\hline $50-60$ & 13 & 11 & 13 & 10 & 13 & 11 \\
\hline $60-70$ & 8 & 13 & 8 & 15 & 5 & 13 \\
\hline $70-80$ & 3 & 8 & 3 & 7 & 4 & 6 \\
\hline $80-90$ & 5 & 7 & 5 & 7 & 3 & 5 \\
\hline $90-100$ & 0 & 2 & 0 & 0 & 0 & 0 \\
\hline 100 & 8 & 20 & 8 & 20 & 8 & 20 \\
\hline Mean & 0.51 & 0.64 & 0.49 & 0.62 & 0.46 & 0.59 \\
\hline Minimum & 0.18 & 0.28 & 0.063 & 0.28 & 0.025 & 0.17 \\
\hline Scale efficiency & & & & 0.79 & & 0.78 \\
\hline
\end{tabular}

Source: Own elaboration from model results and data survey (2019). 
Figure 2 - Cumulative efficiency distribution for both technical and sub-vectors efficiencies.

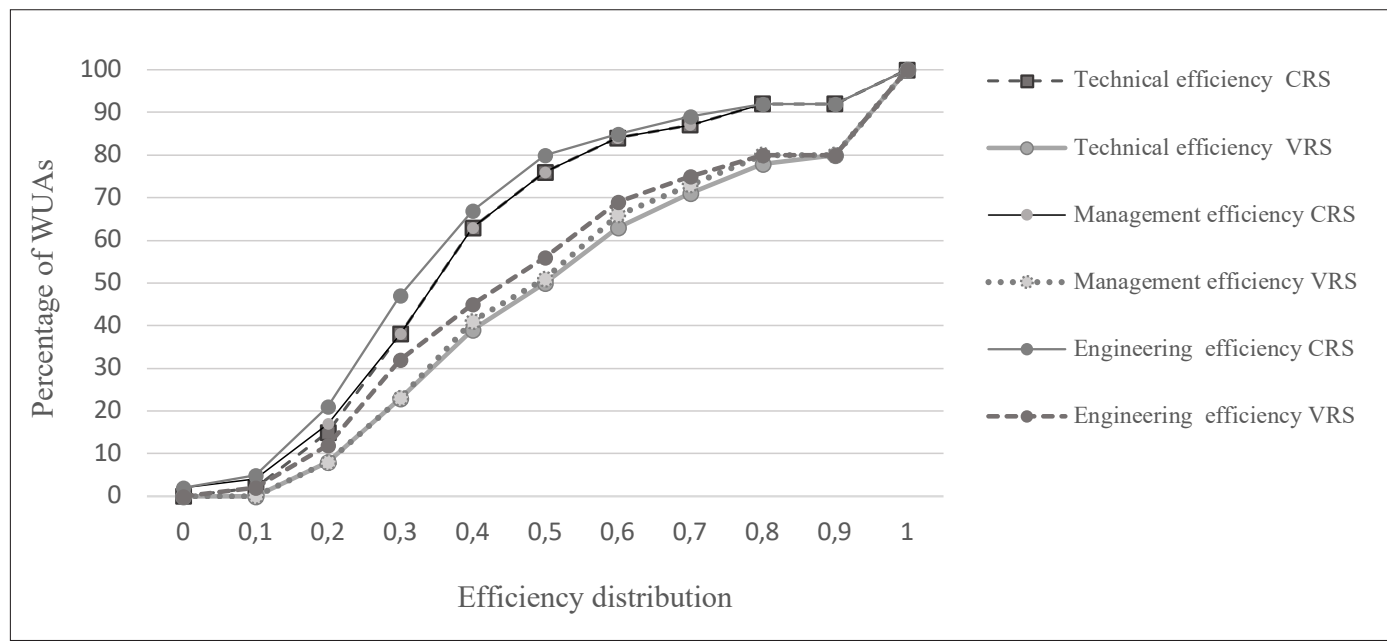

Source: Own elaboration from model results and data survey (2019).

than short to medium term uncontrollable operating scale size that is the major problem for most oases irrigation schemes. Improvement of internal management efficiency should be the first option for reducing operating costs for the WUAs. Based on the SE scores, it was concluded that the examined WUAs use $20 \%$ extra input because they possess a different scale than the optimum size.

Results show also that management and engineering (maintenance) inefficiencies are larger than the overall inefficiency. Average maintenance efficiency is only 0.46 under CRS and 0.59 under VRS, which is much lower than technical efficiency and exhibits greater variability, ranging from $2.5 \%$ and $100 \%$. Mean management efficiency is found to $49 \%$ and $62 \%$ under CRS and VRS formulation, respectively, which is either lower than technical efficiency and exhibits greater variability, ranging from $6.3 \%$ and $100 \%$. Figure 2 depicts the cumulative efficiency distributions, confirming that under CRS and VRS specifications the proportion of WUAs with poor sub-vector management efficiency and engineering sub-vector efficiency is always higher than the proportion of those having poor scores for technical efficiency. This means that WUAs can achieve significant savings in maintenance and management expenditures by improving the way they use the irrigation system and by using more advanced irrigation and agricultural production techniques, even by enhancing the know-how of the techniques and use of the irrigation system.

On the other hand, the study also revealed that the sub-vector inefficiency of WUAs is more linked with engineering inefficiencies than to their inefficiencies in their management. The distribution frequency of the two efficiencies is reported in Figure 3.

Figure 3 shows that nearly $11 \%$ of WUAs belong to the group of weak engineering (maintenance) efficiency (between $[0 ; 25 \%]$ ) while 58\% of them belong to the second group (between $[25 \% ; 50 \%])$ regarding the same criterion. In both groups, we observe that inefficient WUAs in engineering tasks are more frequent than inefficient WUAs regarding management tasks. As a matter of fact, 69\% are inefficient (between $[0 ; 50 \%])$ in engineering, while only $63 \%$ of them are inefficient in management. From the same perspective, $37.5 \%$ of WUAs belong to the groups of good efficiency (between [50\%; 1]) regarding the management efficiency criteria, while only $30 \%$ of them belongs to the same group if we consider engineering efficiency.

By improving technical efficiency, management and maintenance costs can be reduced on average by $48.9 \%$ and $52.7 \%$ per WUA respectively with regard to the good efficiency groups 
Figure 3 - The frequency distribution of efficiency scores. re 2 - Cumulative efficiency distribution for both technical and sub-vectors efficiencies.

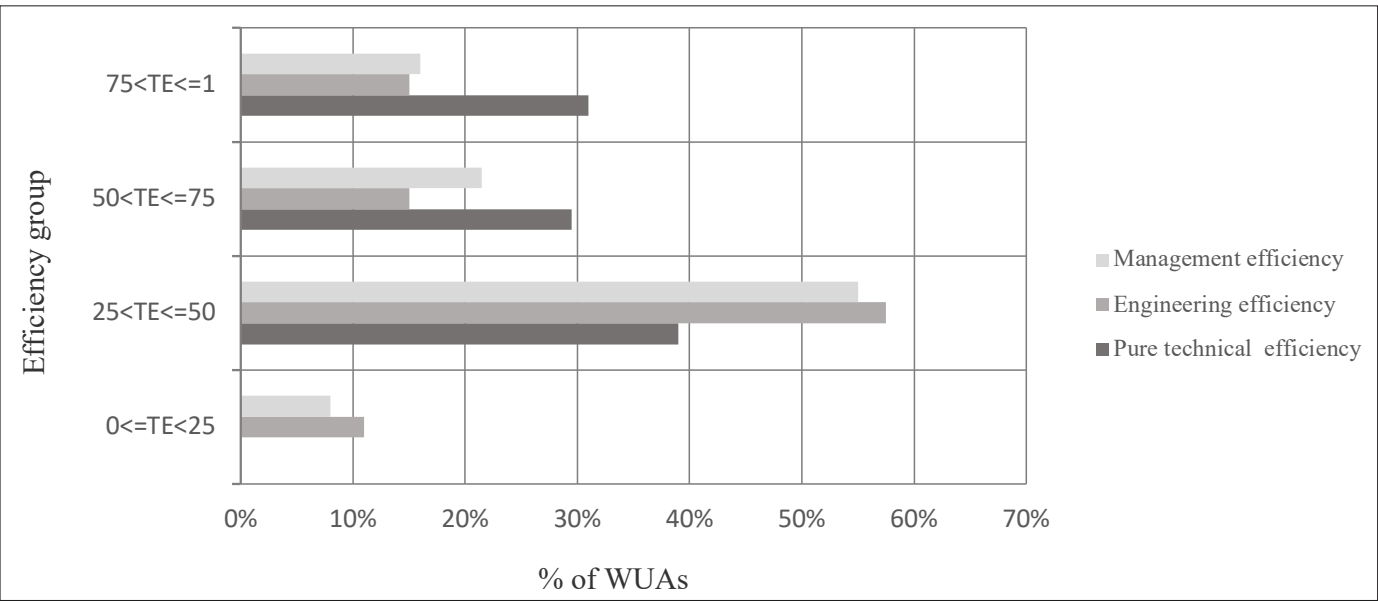

Source: Own elaboration from model results and data survey (2019).

(between $[50 \% ; 1]$ ), and by $62.64 \%$ and $64.1 \%$ per WUA respectively with regard to the inefficient efficiency groups (between [0; 50\%]) (Table 4). When these results will be collectively reviewed, potential costs savings account to $310,997.215$ TDN and 857,052.11 TDN in management and maintenance costs, respectively, which is over a half of the total operating cost of 61 oases irrigation schemes in 2018/2019 (Table 4).

Results also show a great disparity in terms of efficiency among districts (Figure 4). Three $(33.33 \%)$ districts were found to be technically inefficient (between [30; 40\%]), while five of them $(55.55 \%)$ have achieved scores below

Table 4 - Actual and target values and reduction rates for inputs and outputs by efficiency groups.

\begin{tabular}{|c|c|c|c|c|}
\hline Efficiency group & Input / Output & Actual & Target & Reduction (\%) \\
\hline \multirow{4}{*}{$0<\mathrm{TE}<=0.5$} & Management costs & $18,562.6$ & $6,934.87$ & 62.64 \\
\hline & Maintenance costs & $48,254.95$ & $17,318.74$ & 64.10 \\
\hline & Irrigation area (ha) & 109.20 & 109.20 & 0.00 \\
\hline & $\begin{array}{l}\text { Water distributed per } \\
\text { irrigated area }\left(\mathrm{m}^{3} / \mathrm{ha}\right)\end{array}$ & $6,850.22$ & $7,562.57$ & -10.39 \\
\hline \multirow{4}{*}{$0.5<\mathrm{TE}<1$} & Management costs & $12,456.12$ & $8,913.26$ & 28.44 \\
\hline & Maintenance costs & $31,064.45$ & $20,193.24$ & 34.99 \\
\hline & Irrigation area (ha) & 107.64 & 107.64 & 0.00 \\
\hline & $\begin{array}{l}\text { Water distributed per } \\
\text { irrigated area }\left(\mathrm{m}^{3} / \mathrm{ha}\right)\end{array}$ & $8,178.41$ & $8,992.40$ & -9.95 \\
\hline \multirow{4}{*}{ Average } & Management costs & $15,509.38$ & $7,924.065$ & 48.90 \\
\hline & Maintenance costs & $39,659.7$ & $18,755.99$ & 52.7 \\
\hline & Irrigation area (ha) & 108.42 & 108.42 & 0.00 \\
\hline & $\begin{array}{l}\text { Water distributed per } \\
\text { irrigated area }\left(\mathrm{m}^{3} / \mathrm{ha}\right)\end{array}$ & $7,514.315$ & $8,277.485$ & -10.15 \\
\hline
\end{tabular}

Source: Own elaboration from model results and data survey (2019). 
Figure 4 - Engineering and management efficiency by districts.
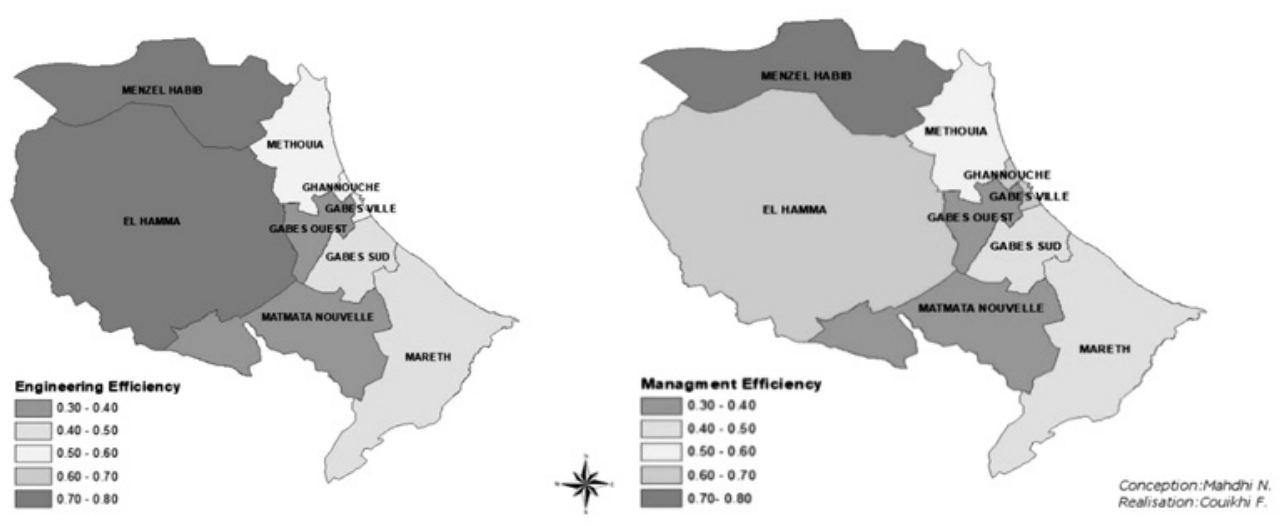

Source: Own elaboration based on model results (2019).

Figure 5 - Percentage of reduction in inputs by districts: (a) management costs and (b) maintenance costs.

(a)

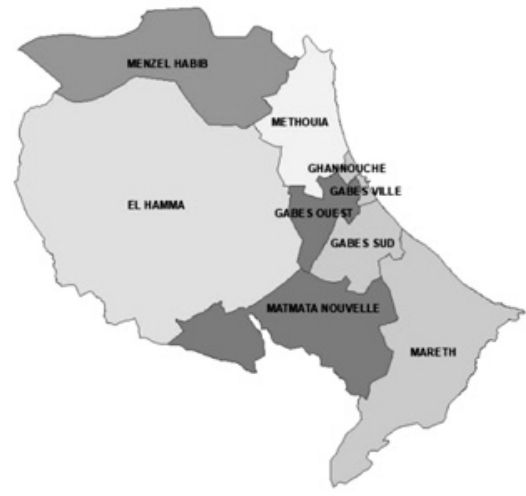

(b)

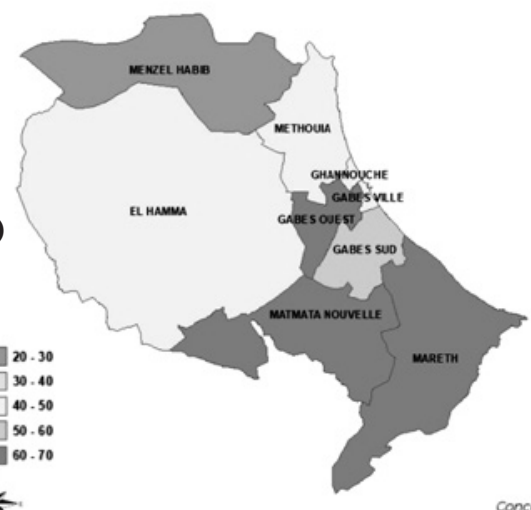
Conception: Mahahi $N$.
Realisation: Coulkhi $F$.

Source: Own elaboration based on model results (2019).

the average in engineering and management efficiency. It is therefore clear that districts with low-efficiency values need to decrease their management and maintenance costs to the level of efficient districts. Figure 5 shows percentages (with respect to current value) by which each district (region) should reduce each one of its inputs in order to become efficient.

\subsection{The determinants of efficiency}

Table 5 reports the estimated coefficients for four separate Tobit regressions. The Tobit regression assumes that the residuals are normally distributed according to Holden (2004). The conditional moment test for normality in censored data (Purmalino et al., 2015) indicated that the normality hypothesis could not be rejected. Furthermore, a log-likelihood test rejected a null hypothesis that all slope parameters were simultaneously nil with statistic tests of $12.14,-16.328,-0.82$ and -3.08 for the four regression, and confirmed that all Tobit models were significant. With a pseudo R square ranging from 0.24 to 0.88 , the model fits were satisfactory for all regressions. 
Table 5 - Factors associated with efficiency scores.

\begin{tabular}{|c|c|c|c|c|c|c|c|c|}
\hline \multirow{3}{*}{$\begin{array}{c}\text { Explanatory } \\
\text { variable }\end{array}$} & \multicolumn{8}{|c|}{ Explained variable } \\
\hline & \multicolumn{2}{|c|}{$S E$} & \multicolumn{2}{|c|}{ Pure TE } & \multicolumn{2}{|c|}{ Mg.Efficiency } & \multicolumn{2}{|c|}{ Eg.Efficiency } \\
\hline & Estimate & P-Value & Est. & P-Val. & Est. & P-Val. & Est. & P-Val. \\
\hline \multicolumn{9}{|c|}{ Tech. char. of the irrig. dist. } \\
\hline $\begin{array}{l}\text { N. of years in } \\
\text { function }\end{array}$ & -0.0012 & 0.282 & -0.0028 & 0.195 & $-0.0027 *$ & 0.09 & $-0.003^{*}$ & 0.094 \\
\hline $\begin{array}{l}\text { N. of water } \\
\text { pumping stations }\end{array}$ & -0.00004 & 0.617 & $-0.0004 * * *$ & 0.001 & $-0.0003 * * *$ & 0.00 & $-0.0003 * * *$ & 0.000 \\
\hline Resource size & $0.0008^{* * *}$ & 0.00 & $0.0017 * * *$ & 0.005 & 0.0001 & 0.664 & 0.0002 & 0.378 \\
\hline $\begin{array}{l}\text { Ratio of water } \\
\text { losses }\end{array}$ & 0.041 & 0.240 & -0.003 & 0.477 & -0.0060 & 0.160 & -0.005 & 0.112 \\
\hline Irrigation ratio & 0.0004 & 0.750 & $0.0038^{*}$ & 0.101 & $0.0029^{*}$ & 0.098 & 0.002 & 0.172 \\
\hline \multicolumn{9}{|c|}{ Administ. and org. charact. of $W U A$} \\
\hline $\begin{array}{l}\text { Ratio of farmers } \\
\text { who are members } \\
\text { of WUAs }\end{array}$ & -0.0002 & 0.911 & 0.0004 & 0.925 & 0.0015 & 0.599 & 0.002 & 0.393 \\
\hline $\begin{array}{l}\text { N. of members in } \\
\text { the administration } \\
\text { council }\end{array}$ & -0.024 & 0.159 & 0.049 & 0.235 & 0.038 & 0.164 & $-0.046^{*}$ & 0.107 \\
\hline Constant & $0.694 * *$ & 0.032 & $0.784 *$ & 0.090 & 0.487 & 0.165 & 0.346 & 0.306 \\
\hline$\Sigma$ & 0.168 & $0.022^{\mathrm{a}}$ & 0.266 & $0.031^{\mathrm{a}}$ & 0.214 & $0.03^{\mathrm{a}}$ & 0.223 & $0.032^{\mathrm{a}}$ \\
\hline Pseudo $\mathrm{R}^{2}$ & \multicolumn{2}{|l|}{0.415} & \multicolumn{2}{|l|}{0.249} & \multicolumn{2}{|l|}{0.88} & \multicolumn{2}{|l|}{0.61} \\
\hline $\begin{array}{l}\text { Log-pseudo- } \\
\text { likelihood test }\end{array}$ & \multicolumn{2}{|c|}{-12.14} & \multicolumn{2}{|c|}{-16.328} & \multicolumn{2}{|c|}{-0.82} & \multicolumn{2}{|c|}{$-3,08$} \\
\hline $\begin{array}{l}\text { Test value CM } \\
\text { Normality }\end{array}$ & \multicolumn{2}{|c|}{$x^{2}=34.85$} & \multicolumn{2}{|c|}{$x^{2}=43.92$} & \multicolumn{2}{|c|}{$x^{2}=53.54$} & \multicolumn{2}{|c|}{$x^{2}=44.38$} \\
\hline N. of observations & \multicolumn{2}{|c|}{61} & \multicolumn{2}{|c|}{61} & \multicolumn{2}{|c|}{61} & \multicolumn{2}{|c|}{61} \\
\hline
\end{tabular}

Note: *, **, ***= significant at 10,5 and $1 \%$ level respectively. ${ }^{a} F$ or $\sigma$ the standard error is reported instead of the P-value. Source: Own elaboration from Tobit model results (2019).

Concerning the individual variables, the results of Tobit models showed consistency. Most of the estimated coefficients of the technical characteristics of the irrigated district were significant, whereas mainly administrative and organizational characteristics of the WUA were not significant in all models. The number of years in functioning, the number of water pumping stations and the irrigation ratio negatively influenced technical efficiency and management and maintenance costs sub-vectors efficiencies, while the other significant variables (the irrigation length of the water carrier, the ratio of water losses) had a positive effect on the efficiency measures.

While looking at the scale efficiency measure, the estimated coefficients of resource size, ratio of water losses, irrigation ratio and the number of members in the administration council were positive, whereas the number of years in functioning, the number of water pumping stations and the ratio of farmers who are members of WUAs were negative. Among these variables, only the estimated coefficient of the length of the irrigation water carrier was significant at a $1 \%$ level. 
For the pure technical efficiency scores, technical variables are statistically significant. As a matter of fact, we found that the number of water pumping stations and the irrigation ratio have a significant negative effect, whereas resource size has a positive effect on the efficiency measures of WUAs. The other technical characteristics (number of years in functioning, the ratio of water loss) have a negative but not significant effect on the pure technical efficiencies. Table 5 also presents the results for the two Tobit estimates when the dependent variables are management and engineering efficiency scores, respectively. For both regressions, the number of years in functioning and number of water pumping stations have a negative and statistically significant effect at $5 \%$ and $1 \%$ levels, respectively, whereas the ration of water losses has a positive effect on the efficiency measures. In addition, management efficiency was found to be also negatively affected by the irrigation ratio. Remaining independent variables had no significant effect on both dependent vectors.

\section{Discussion}

The study used a DEA approach to measure the technical, management and engineering efficiencies for WUAs in an oasis-irrigated region in Southeastern Tunisia. The Sub-vector Data Envelopment Analysis has been used for the first time to assess management and engineering efficiencies that express the performance of a given WUA in terms of allocating expenses for internal management, functioning activities, and maintenance tasks. The major finding shows that $80 \%$ of irrigation schemes are not technically efficient and $57.37 \%$ of them have technical efficiency scores below the average level of 62.5 , compared to an average scale efficiency score of 81.9. Thus, the problem of irrigated WUAs is mostly related to management rather than to the inefficiency scale. Based on the SE scores, the WUAs have used $19.1 \%$ extra input because they possess a different scale than the optimum size. This finding confirms the inefficiencies reported by Umetsu et al. (2005), Sayin and Yilmaz (2015) in Turkey, Ntantos and Karpouzos (2010) in Greece, Frija et al. (2008) in
Tunisia. However, Fujiie et al. (2005) and Frija et al. (2008) found that collective action in local water management is difficult to establish when the size of the association (measured by its service area) is large. In our case, we can conclude that an adjustment of the scale could improve the global efficiency and the use of financial resources in Tunisian WUAs.

The calculated management and engineering sub-vector efficiency show poor performance in terms of allocating expenses for internal management and functioning activities, but also in terms of allocating expenses for maintenance tasks. As a matter of fact, operation and maintenance are among the main WUA expenditures. However, important losses in those financial tasks were assessed in the present study, despite the objective fixed by the government to cover the total maintenance and operation costs.

The low level of sub-vector efficiency of WUAs is explained by major problems caused by the lower irrigation ratios, over-irrigation, insufficient maintenance and repair services, challenges in the collection of water fees, the need for rehabilitation of facilities, inadequacy of new investments, and inability to encourage producers to participate in the management of irrigation systems. Irrigation facilities must be operated efficiently and effectively in order for WUAs providing water distribution services to continue to exist and to carry out their activities successfully.

This is consistent with several reviews on WUAs in the literature that reported the two most prominent criticisms of WUAs to be found are the unrealistic expectations on cost recovery and the inability to promote an inclusive user participation during the implementation of irrigation projects (Aarnoudse et al., 2018).

The result of Tobit models shows that resource size (irrigation network), the age of WUA, the number of pumping stations and the irrigation ratio have a significant impact on efficiency measures. Among these variables, the estimated coefficients of the resource size affected positively scale and pure technical efficiency. Thus, the WUAs with a larger size could lead to a more efficient scale of operation than the smaller size, as measured by the length of their level canals. This is consistent with the argument reported 
by Bardhan (2000), Frank and Ward (2010) and Zema et al. (2018) who confirmed that the adoption of growing size policies allows to obtain economies of scale and better financial and organizational performances, as well as lower costs of the irrigation service for the larger WUAs. Our first field inspections confirm this finding. However, in order to benefit from this greater efficiency and the scale effect, a modernization of irrigation techniques should be encouraged. Other important factors, which had a significant impact on purely technical and sub-vector efficiencies, were the number of years in function and the number of pumping stations managed by a given WUA. The age of a WUA has a negative and highly significant impact. In contrast, older associations are expected to be more stable (Frija et al., 2008; Huang, 2014). Nevertheless, this result can be interpreted in two ways. Over time, irrigation networks get older and the experience of management matters in terms of maintenance. Therefore, their renewal will be more expensive. Huang (2014) reported that maintenance costs increase proportionally with the manager's experience. For this reason, older WUAs require a higher budget especially for maintenance and management tasks, which can influence their global efficiency and lead to resource losses. Therefore, the modernization of irrigation techniques, good network management, and renewal strategies could be a solution. However, in most cases, the WUAs members are not qualified enough to ensure the management and technical supervision: the elaboration of a global optimal management plan will be a difficult task, thus, governmental assistance will be needed. The second explanation of the negative impact of the WUA's age can be reported as a non-social sustainability between the members of the association. According to Meinzen-Dick et al. (2002), older organizations seem to be more stable due to the lack of trust and the presence of social conflicts between members of the association. For the Tunisian case, some specific studies (Frija et al., 2017) report the existence of such conflicts and the weak social relationships between farmers and members in the Tunisian WUAs. The number of pumping stations managed in a given WUA has a negative impact too. As a matter of fact, each pump is used by a group of farmers. The effect of the number of users of the irrigation system can be ambiguous. This is probably due to the difficulty in coordinating water deliveries increasing with the group size. These findings validate the early work of Olson (1965) and Weissing and Ostrom (1990) cited in Bardhan (2000), Meinzen-Dick et al. (2002) and Wang et al. (2010) cited in Zhang et al. (2013), which shows that collective action is easier to organize and monitor in smaller groups. They mentioned that a large group size may negatively affect collective management of water and intensify problems of free riding. Zhang et al. (2013) indicated that this effect was not significant. According to our first field inspections, the timing of the pumping is always a source of conflict between farmers who want to irrigate at the same time. An increase in the number of pumps and the creation of sub-councils of farmers could be good alternatives to improve the global efficiency of WUAs. Finally, the irrigation ratio had a significant positive impact on pure technical and management efficiencies. This suggests that an improvement of this ratio could lead to greater efficiency. It also has a positive impact even on the scale, and engineering efficiencies. These findings match with the work of Zema et al. (2018) in Calabria (Southern Italy). An increase in the irrigation ratio should be one of the main activities to be encouraged by managers to improve the performance of irrigation. Since the number of governing board members affects the scale and engineering efficiency, the reduction in their members would improve the scale efficiency.

\section{Concluding remarks and policy implications}

This study has carried out a comprehensive analysis of the efficiency of collective irrigation sectors in oases areas, where irrigated agriculture plays an important role in the economic sector and the hydrological risk is pressing. The combined use of DEA and Tobit models seems to be a very useful tool for efficiency assessment and the identification of factors that determine overall management and maintenance efficiencies, as well as scale efficiency of the Tunisian 
WUAs. The organizations studied were particularly complex for many reasons. As a matter of fact, multiple objectives and different targets can be pursued, leading to bias in some annual stated inputs, which can be used in the DEA models.

The DEA analysis highlights the fact that management and maintenance tasks are important criteria in determining the WUAs' overall performance and efficiency. DEAs allowed, firstly, the identification of the inefficient WUAs and the performance of the remaining collective organizations (considered efficient) to be employed as reference. It is then clear that districts with low-efficiency values need to decrease their management and maintenance costs to the level of efficient WUAs. Therefore, the modernization of irrigation techniques, good network management and renewal strategies could be a solution. In WUA, irrigation facilities must be operated efficiently and effectively in order for the organizations providing water distribution services to continue to exist and successfully carry out their activities. Aside from a proper planning, design and construction of irrigation networks, efficient operation is crucial. Indeed, the scarcity of resources tend to push WUAs in oases areas to use resources more efficiently, which brings the concept of efficiency to the fore. For these organizations, characterized by a limited funding (i.e., collected water fees), the concept of efficiency is crucial in turning water distribution service expenditures into outputs. The major finding regarding the determinations of WUAs' efficiency concerns the negative effect of the association's age and the pumps' number on its performance. This raises some questions about the sustainability of these WUAs, which should be investigated. Globally, the technical characteristics of the irrigated districts and network have a significant impact on all efficiency measures. However, mainly administrative and organizational characteristics of the WUA were not statistically significant.

The findings provided in this research suggest that more analysis of the Tunisian WUAs should be undertaken in order to clarify some additional aspects of the structure and the functioning of WUAs. For further analysis, a comprehensive assessment of WUAs' management and produc- tivity in oases areas, compared to other regions of Tunisia, may be necessary to understand and predict future scenarios for WUAs.

A comparative context-specific classification of WUAs under specific typologies will certainly help the assessment of different understandings and experiences among water stakeholders and key factors, other than formal organization, in the management of participatory irrigation. It was also important to study the effectiveness and sustainability of water resources for the development and for the ecosystem in the south of Tunis and how WUAs can disseminate the information (or advice) to the public.

Because of lack of available data, environmental factors such as soil quality, gradient, salinity conditions in each WUA were not considered. It may be worthwhile to separate the external environmental factors that may be affecting management practices when a data set is available. The WUAs contribution in improving water efficiency and their wide impact of water use and allocation still need to be further investigated. In view of the future consequences of climate change and water scarcity in the region, the role of WUAs for an efficient management of water resources seems important. Finally, greater reflection is needed to understand the limitations of WUAs and to offer alternative, viable and context-based adapted models.

\section{References}

Aarnoudse E., Closas A., Lefore N., 2018. Water user associations: a review of approaches and alternative management options for Sub-Saharan Africa. IWMI Working Paper 180. Colombo, Sri Lanka: International Water Management Institute. doi: 10.5337/2018.210.

Abdedayem S., 2009. Raréfaction de l'eau dans les oasis : crise de la ressource ou crise de gouvernance ? Cas des oasis du Sud-Est tunisien. In : Ayeb H. et Ruf T. (dir.), Eaux, pauvreté et crises sociales - Water, poverty and social crises. Marseille : IRD Editions, pp. 409-422.

Abdelhafidh H., Bachta M.S., 2016. Groundwater pricing for farms and water user association sustainability. Arabian Journal of Geosciences, 9: 525.

Al Atiri R., 2007. Evolution institutionnelle et réglementaire de la gestion de l'eau en Tunisie. Vers 
une participation accrue des usagers de l'eau. In : Bouarfa S., Kuper M., Debbarh A. (éds.), L'avenir de l'agriculture irriguée en Méditerranée. Nouveaux arrangements institutionnels pour une gestion de la demande en eau, Actes du séminaire Wademed, Cahors, France, 6-7 novembre 2006. Montpellier, France : CIRAD.

Bachta M.S., Ghersi G., 2004. Agriculture and Food in the Mediterranean: the challenges of globalization. Montpellier, France: Editions Karthala / CHIHEAM / IRESA (in French).

Bachta M.S., Zaïbet L., 2007. The institutional innovations as adaptations to the changing environment of irrigated areas: the case of Tunisia. In : Bouarfa S., Kuper M., Debbarh A. (éds.), L'avenir de l'agriculture irriguée en Méditerranée. Nouveaux arrangements institutionnels pour une gestion de la demande en eau, Actes du séminaire Wademed, Cahors, France, 6-7 novembre 2006. Montpellier, France : CIRAD.

Banker R.D., Charnes A., Cooper W.W., 1984. Some models for estimating technical and scale inefficiencies in data envelopment analysis. Management Science, 30(9): 1078-1092.

Bardhan P., 2000. Irrigation and Cooperation: An Empirical Analysis of 48 Irrigation Communities in South India. Economic Development and Cultural Change, 48(4): 847-865.

Belloumi M., Matoussi M.S., 2007. Impacts de la salinité sur l'efficience technique de l'agriculture irriguée : application au cas des Oasis de Nefzaoua en Tunisie. Economie et Prévision, 1(177): 77-89.

Ben Mustapha A., Faysse N., 2017. Pratiques de coordination dans les Groupements de Développement Agricole en Tunisie : des coalitions actives mais fragiles. Alternatives Rurales, 5: 1-16.

Ben Mustapha A., Faysse N., Marlet S., Jamin J.Y., 2015. Une action collective analysée par ses acteurs : une association d'irrigants en Tunisie. Natures Sciences Sociétés, 4(23): 356-366.

Ben Nasr J., Bachta M.S., 2018. Conflicts and water governance challenge in irrigated areas of semi-arid regions. Arabian Journal of Geosciences, 11: 753.

Binam J.N., Sylla K., Diarra I., Nyambi G., 2003. Factors Affecting Technical Efficiency among Coffee Farmers in Côte d'Ivoire: Evidence from the Centre West Region. African Development Review, 15(1): 66-76.

Boukchina R., Abdedayem S., 2008. Programme Régional d'Economie d'Eau d'Irrigation dans le Gouvernorat de Gabès: Essai d'évaluation. New Medit, $7(2): 31-35$.

Carpentier I., 2017. Diversité des dynamiques locales dans les oasis du Sud de la Tunisie. Cahiers Agricultures, 26(3): 35001.

Charnes A., Cooper W.W., Rhodes E., 1978. Measuring the efficiency of farms. European Journal of Operational Research, 2(6): 429-444.

Coelli T., 1996. A guide to DEAP version 2.1: A data envelopment analysis (computer) program. CEPA Working Paper 96/08. Centre for Efficiency and Productivity Analysis, University of New England, Armidale, Australia.

CRDA (Commissariat Régional au Développement Agricole of Gabès), 2017. Annual reports of the agricultural sector in the Governorate of Gabès. Administrative (unpublished reports). Ministry of Agriculture, Tunisia.

Diaz Rodriguez J.A., Poyato C.E., Luque L.R., 2004. Applying benchmarking and data envelopment analysis (DEA) techniques to irrigation district in Spain. Irrigation and Drainage 53: 135-143.

Elloumi M., 2016. La Gouvernance des eaux souterraines en Tunisie. IWMI Project Report No. 7. Colombo, Sri Lanka: International Water Management Institute.

Emlyaeih T., 2016. Analyse de la performance productive de l'agriculture oasienne. Cas de l'Oasis de Chenini Gabès. Projet de fin d'étude, Ecole Supérieure d'Agriculture de Mograne, Tunisie.

Farrell M.J. (1957). The measurement of productive efficiency. Journal of the Royal Statistical Society, ser. A, 120(3): 253-290.

Frank A., Ward A., 2010. Financing Irrigation Water Management and Infrastructure: A Review. International Journal of Water Resources Development, 26(3): 321-349.

Frija A., Chebil A., Speelman S., Buysse J., Huylenbroeck V.G., 2009. Water use and technical efficiencies in horticultural greenhouses in Tunisia. Agricultural Water Management, 96: 1509-1516.

Frija A., Chebil A., Speelman S., Faysse N., 2014. A Critical Assessment of Groundwater Governance in Tunisia. Water Policy, 16: 358-373.

Frija A., Speelman S., Chebil A., Buysse J., Huylenbroeck G.V., 2008. Performance and efficiencies of the irrigation water users' association in Tunisia. Paper presented at the 107th EAAE Seminar "Modelling of Agricultural and Rural Development Policies", January 29th - February 1st, Sevilla, Spain.

Frija A., Zaatra A., Frija I., Abdelhafidh H., 2017. Mapping Social Networks for Performance Evaluation of Irrigation Water Management in Dry Areas. Environmental Modeling \& Assessment, 22: 147-158.

Fujiie M., Hayami Y., Kikuchi M., 2005. The condi- 
tions of collective action for local commons management: the case of irrigation in the Philippines. Agricultural Economics, 33(2): 179-189.

Huang Q., 2014. Impact evaluation of the irrigation management reform in northern China. Water Resources Research, 50(5): 4323-4340.

Hamza M., 2008. Status, challenges and strategic axes of water sector in Tunisia. Paper presented at the First African Water Week (AWW-1), March 2628, Tunis (in French).

Holden D., 2004. Testing the Normality Assumption in the Tobit Model. Journal of Applied statistics, 31: 521-532.

Gana A., El Amrani M., 2006. Crise hydraulique au Maghreb : raréfaction de la ressource ou problèmes de gestion ? Géocarrefour, 81(1): 1-23.

Gana A., Fouillen B., 2014. Concurrences et conflits pour l'usage de l'eau en Tunisie : étude de cas dans la région du Cap Bon. Le Carnet de l'IRMC, 21 février 2014. http://irmc.hypotheses.org/1412.

Ghazouani W., Merlet S., Mekki I., Harrington L.W., Vidal A., 2012. Farmers' practices and community management of irrigation: why, do they not match in Fatnassa oasis. Irrigation and Drainage, 61: 39-51.

Louati M.H., 2008. Efficiency of water use: a case study of Tunisia. Plan Bleu, Meeting of Experts, 5 November (in French).

INS (Institut National de la Statistique), 2016. Annuaire Statistique de la Tunisie 2011-2015. Tunis : Institut National de la Statistique.

ITES (Institut Tunisien des études stratégiques), 2011. Etude stratégique : Eau 2050 en Tunisie. Rapport de synthèse.

ITES (Institut Tunisien des études stratégiques), 2014. Etude stratégique: Système hydraulique de la Tunisie à l'horizon de 2030.

Mahdhi N., Sghaier M., 2013. The Technical Efficiency of Collective Irrigation Schemes in South-Eastern of Tunisia. International Journal of Sustainable Development \& World Policy, 2(7): 87-100.

Mahdhi N., Sghaier M., 2017. Essais de réglementation des prélèvements agricole en eau souterraine dans un contexte d'asymétrie d'information : cas des périmètres publics irrigués, Sud-est Tunisien. New Medit, 16(3): 62-72.

Mahdhi N., Sghaier M., Bachta M.S., 2011. Water use and technical efficiencies in private irrigated perimeters in South-Eastern of Tunisia. Emirates Journal of Food and Agriculture, 23(5): 440-451.

Mahdhi N., Sghaier M., Fouzai A., 2019 : Eau et changement climatique: quelles stratégies d'adaptation pour la gestion de l'eau d'irrigation dans le sud-est Tunisien, New Medit, 18(1): 15-28.

Mahdhi N., Sghaier M., Smida Z., 2014: Efficiency of the irrigation water users' association in Zeuss-koutine region, south-eastern Tunisia. New Medit, 13(2): 47-55.

Makkaoui R., 2006. Les nouvelles modalités de gestion de l'eau dans les pays en développement : de la dynamique institutionnelle aux pratiques quotidiennes. Le cas des associations d'usagers de l'eau agricole. Communication au Colloque International sur la gestion concertée des ressources naturelles et de l'environnement, du local au mondial : pour un dialogue entre chercheurs, société civile et décideurs. Université de Versailles, Saint-Quentin en Yvelines 26-28 juin.

Makkaoui R., Dubois J.L., 2010. Nouvelles formes de gouvernance dans le domaine de l'eau. Apports et limites de la coopération décentralisée dans les pays en développement. Développement durable et territoires, 1(1): 1-19.

Malano H., Burton M., Ian M.I., 2004. Benchmarking performance in the irrigation and drainage sector: a tool for change. Irrigation and Drainage, 53: 119-133.

Marlet S., Mnajja A., 2017. Transfert de la gestion des périmètres publics irrigués aux associations d'irrigants en Tunisie. Tome 1. Mise en cuvre et adaptation de la stratégie nationale. Retour d'expérience du projet PAP-AGIR pour l'autonomie progressive des associations. Montpellier, France : CIRAD.

Meinzen-Dick R., Raju K.V., Gulati A., 2002. What affects organization and collective action for managing resources? Evidence from canal irrigation systems in India. World Development, 30(4): 649-666.

MA (Ministry of Agriculture and Water Resources), 2010. XIIth Development Plan (2010-2014). Report (in Arabic) of the Commission's sectoral Agricultural Development, Fishing and Natural Resources.

MA (Ministry of Agriculture and Water Resources), 2013. Economic budget for the year 2013. Arab report.

MA (Ministry of Agriculture and Water Resources), 2016. National report of water (in French).

Ntantos P.N., Karpouzos D.K., 2010. Application of data envelopment analysis and performance indicators to irrigation systems in Thessaloniki Plain (Greece). World Academy of Sciences, Engineering and Technology, 4(10): 53-59.

Oude Lansink A., Pietola K., Bäckman S., 2002. Efficiency and productivity of conventional and organic farms in Finland 1994-1997. European Review of Agricultural Economics, 29(1): 51-65. 
Oude Lansink A., Silva E., 2004. Non-parametric production analysis of pesticides use in the Netherlands. Journal of Productivity Analysis, 21: 49-65.

Ouneis H., 2018. Stratégies d'adaptation des agriculteurs face à la dégradation des ressources hydriques : cas de l'agriculture. Projet de fin d'étude, Ecole Supérieure d'Agriculture de Mograne, Tunisie.

Özmen S., Kamanb H., 2015. Assessing the Performance of Irrigation Schemes in Antalya Valley Located in Mediterranean Region of Turkey. Water Resources, 42(3): 397-403.

Purmalino A., Saefuddin A., Wijayanto H., 2015. Alternative semi-parametric estimation for non-normality in censored regression model with large number of zero observation (case study: LPG demand on household sector). Indonesian Journal of Statistics, 20(2): 64-67.

Romagny B., Riaux J., 2007. La gestion communautaire de l'eau agricole à l'épreuve des politiques participatives : regards croisés Tunisie/Maroc. Journal des Sciences Hydrologiques, 52(6): 1179-1196.

Romdhane A., Abdeladhim M., 2008. Evolution des systèmes oasiens et comportements des exploitants agricoles. Cas des oasis littorales, sud-est tunisien. New Medit, 7(2): 17-22.

Romdhane A., Ben Abed M., Abdeladhim M., 2006. Dynamiques et stratégies des exploitants agricoles. Cas des oasis littorales, sud-est tunisien. New Medit, 5(4): 53-59.

Sayin B., Yilmaz I., 2015. Comparing the Relative Efficiency of Irrigation Unions in Antalya, Turkey: A Data Envelopment Analysis. Water Economics and Policy, 1(1): 1450005.

Speelman S., D'Haese M., Buysse J., D'Haese L., 2007. Technical efficiency of water use and its determinants, study at small-scale irrigation schemes in North-West Province, South Africa. Paper presented at the 106th EAAE Seminar "Pro-poor development in low income countries. Food, agriculture, trade and environment". October 2007, Montpellier, France.

Terraux J.P., Gleyses G., Loubier S., 2002. Determining the cost of irrigation water: Method and application. International Commission on Irrigation and Drainage (ICID), Eighteenth Congress. Montreal, 2002 (in French).

Umetsu C., Donma S., Nagano T., Coşkun Z., 2005. The efficient management of Water User Associations: The case of Lower Seyhan Irrigation Project in Turkey. Paper presented at EcoMod2005, International Conference on Policy Modeling, June 29 - July 1, Istanbul, Turkey.

Yilmaz B., Yurdusev M.A., Harmancioglu N.B., 2009. The Assessment of Irrigation Efficiency in Buyuk Menderes Basin. Water Resources Management, 23: 1081-1095.

Zema D.A., Nicotra A., Mateos L., Zimbone S.M., 2018. Improvement of the irrigation performance in Water Users Associations integrating data envelopment analysis and multi-regression models. Agricultural Water Management, 205: 38-49.

Zema D.A., Nicotra A., Tamburino V., Zimbone S.M., 2015. Performance assessment of collective irrigation in water users' associations of Calabria (Southern Italy). Irrigation and Drainage, 64(3): 314-325.

Zhang L., Heerink N., Dries L., Shi X., 2013. Water users' associations and irrigation water productivity in Northern China. Ecological Economics, 95: 128-136.

Zhou Q., Deng X., Wu F., Li Z., Song W., 2017. Participatory Irrigation Management and Irrigation Water Use Efficiency in Maize Production: Evidence from Zhangye City, Northwestern China. Water, 9(11): 822 . 